\title{
EXTRACTION, CHEMICAL COMPOSITION OF PEEL AND KERNEL MANGO EXTRACTS AND THEIR ANTIMICROBIAL EFFECT ON THE PRODUCTION AND CHARACTERISTICS OF MINAS FRESCAL CHEESE
}

\section{Extração, composição química dos extratos de caroço e casca de manga e seu efeito antimicrobiano na produção e características de queijo Minas Frescal}

\begin{abstract}
Taila Posseti ${ }^{1}$, Wanderson de Oliveira Santos ${ }^{2}$, Geoffroy Roger Pointer Malpass ${ }^{1}$, Mônica Hitomi Okura ${ }^{I}$, Ana Claudia Granato ${ }^{1 *}$
\end{abstract}

\begin{abstract}
Minas Frescal cheese is one of the most commercialized products in Brazil, but due to its high moisture, it is very perishable. To increase the shelf life of foods, many bioactive extracts have been used as preservatives, as they have antimicrobial action. The mango peel and kernel are industrial residues and have phenolic compounds with antimicrobial activity. This study aimed to develop Minas Frescal cheeses incorporating both peel and kernel mango extracts, to evaluate their physicalchemical and microbiological characteristics, as well as their sensory acceptance. The addition of the extracts did not change the physical-chemical characteristics of the product, except for the $\mathrm{pH}$ that showed a significant reduction and an increase in the titratable acidity. Thus, it is concluded that the lower the $\mathrm{pH}$ and the greater the number of phenolic compounds present in the extract, the greater the effect of antimicrobial activity will be. The averages attributed by the participants in the sensory analysis indicated a preference for cheeses with Espada and Tommy Atkins mango extract, demonstrating the potential use of these extracts in the production of Minas Frescal cheese.
\end{abstract}

Keywords: antimicrobial extracts; sensorial analyses; milk.

1 Universidade Federal do Triângulo Mineiro, Av. Frei Paulino, 30, Abadia, 38025-180, Uberaba, MG, Brasil.E-mail:ana.malpass@uftm.edu.br

2 Ourofino Agrociências, Uberaba, MG, Brasil.

* Autor para correspondência

Recebido / Received: 26/07/2020

Aprovado / Approved: 21/10/2020 


\section{RESUMO}

O queijo Minas Frescal é um dos produtos mais comercializados no Brasil, e por possuir alta umidade é muito perecível. Para aumentar a vida útil dos alimentos, muitos extratos bioativos têm sido utilizados como conservantes, pois apresentam ação antimicrobiana. A casca e caroço de mangas são resíduos industriais que possuem compostos fenólicos com atividade antimicrobiana. Este estudo teve como objetivo o desenvolvimento de queijos Minas Frescal incorporando extratos de casca e caroço de manga, avaliar suas características físico-químicas e microbiológicas, bem como sua aceitação sensorial. A adição dos extratos não alterou as características físicoquímicas do produto, exceto pelo $\mathrm{pH}$ que apresentou redução significativa e aumento da acidez titulável. Assim, conclui-se que, quanto menor o $\mathrm{pH}$ e maior o número de compostos fenólicos presentes no extrato, maior o efeito da atividade antimicrobiana. As médias atribuídas pelos participantes na análise sensorial indicaram preferência por queijos com extrato de manga Espada e Tommy Atkins, demonstrando o potencial de uso desses extratos na produção de queijo Minas Frescal.

Palavras-chave: extrato antimicrobiano; análise sensorial; leite.

\section{INTRODUCTION}

Minas Frescal cheese is a fresh, soft, white cheese, lightly salted and slightly acidic. In Brazil, Frescal cheese is the third in cheese production, with approximately 34,000 tons being produced (LOLLO et al., 2015). However, the characteristics of this product favour the growth of contaminating microbiota. Increasing consumer demand for natural food products has exerted pressure on industry and regulatory agencies to seek alternative non-traditional preservation methods. Thus, the use of natural antimicrobial agents to prevent/control pathogen growth and spoiling agents in food is a growing research area (LOLLO et al., 2015).

Mango (Mangifera indica L.) is known for its succulence, exotic flavour, and delicious taste, but it is also an important source of vitamin $\mathrm{A}, \mathrm{B}$, and $\mathrm{C}$ and minerals (RAVANI et al., 2013). Mango is one of the most consumed fruits, is extensively commercialized, with cultivation occurring in many countries (RUALES et al., 2018). If the fresh fruit is not considered, $\sim 20 \%$ of harvested mango is industrially processed. According to Trigo et al. (2019), food loss and food waste processing represent an additional cost of $\sim 990$ billion dollars. However, during industrial processing, a large quantity of the fruit is removed in the form of peel and kernel waste $(35-60 \%$ total fruit weight), annually generating several million tons of waste. It is interesting to note that the mango peel and kernel present high levels of active phytochemicals, which are probably responsible for the antioxidant capacity of this fruit (RUALES et al., 2018; DORTA et al., 2012). Mango by-products have been studied as natural and safer alternatives to currently used synthetic antioxidants. These studies have an impact both on the environmental level in reducing pollution from the mango industry, and on the economy, when they contribute to more sustainable production (RUALES et al., 2018).

Abdalla et al. (2007) demonstrated that the methanolic extract of Egyptian mango kernel reduced total bacterial count, inhibited coliform growth, and demonstrated significant 
antioxidant and antimicrobial activity against Escherichia coli, in addition to prolonging the shelf life of pasteurized milk. Thus, the objective of this study was to verify the antimicrobial effect of peel and kernel mango extract in Minas Frescal cheeses, their chemical composition, and sensorial analysis.

\section{MATERIAL AND METHODS}

\section{Obtaining peels and kernels}

Mangoes (Mangifera indica var. Coquinho, Espada, and Tommy Atkins) were purchased locally in Uberaba, MG. The maturation stages were considered, the yellowish colour of the peel, for both the Coquinho and Espada mangoes, and the pinkreddish peel for the Tommy Atkins variety. For the three varieties, the consistency of the fruits was observed, which should be soft but firm. The fruits were washed with a neutral detergent solution $(2.0 \mathrm{~mL} / \mathrm{L})$ for 5 mins for removal of the soil and vegetable debris followed by running water, to remove excess detergent. Sanitization was carried out by immersion in hypochlorite solution $(100 \mathrm{~mL} / \mathrm{L})$ for $15 \mathrm{~min}$. The fruits were subsequently dried at room temperature for $10 \mathrm{~min}$ and manually peeled, removing the peel, the pulp, and the kernel.

\section{Peels/kernel ethanolic extraction}

Both peels and kernels of Coquinho, Espada, and Tommy Atkins mango varieties were oven-dried at $50{ }^{\circ} \mathrm{C}$ for $24 \mathrm{~h}$. Then, materials were triturated, and $500 \mathrm{~g}$ of each sample was added separately to Erlenmeyer flasks with $900 \mathrm{~mL}$ of ethanol (70\%), sheltered from light, and left to rest for 7 days $\left(25^{\circ} \mathrm{C}\right)$ for complete extraction. The material was then filtered, and the extract concentrated using a rotary evaporator at $90{ }^{\circ} \mathrm{C}$ obtaining the ethanolic extract according to the technique described by Barreto et al. (2008). Finally, extracts of the same samples were collected, giving 3 peel extracts (Coquinho $=$ PECM, Espada $=$ PEEM and Tommy Atkins mango $=$ PETAM) and 3 kernel extracts (Coquinho = KECM, Espada = KEEM and Tommy Atkins $=$ KETAM).

\section{Gas Chromatography with Mass Spectrometry Detector (GC-MS)}

Samples were injected into a Shimadzu 2010 High Resolution Gas Chromatograph with Mass Spectrometry Detector using an Agilent DB-5MS column $(30 \mathrm{~m} \times 0.25 \mathrm{~mm}$ $\times 0.25 \mu \mathrm{m})$ with the following conditions: Injector Temperature of $220{ }^{\circ} \mathrm{C}$, Splitless Injection Mode, 2 min sampling time, linear velocity 15.7 Psi Pressure, Total flow of $19.4 \mathrm{~mL} / \mathrm{min}$, Column flow of $1.49 \mathrm{~mL} / \mathrm{min}$, Linear velocity of $45.0 \mathrm{~cm} / \mathrm{s}$, Purge flow of $3.0 \mathrm{~mL} / \mathrm{min}$, Split ratio of 10, Gradient Mode column temperature of $80-280{ }^{\circ} \mathrm{C}$. The Mass Spectrometry Detector parameters were: $200{ }^{\circ} \mathrm{C}$ ion source temperature, $280{ }^{\circ} \mathrm{C}$ interface temperature, $3 \mathrm{~min}$ solvent cut-off time, $3 \mathrm{~min}$ initial detection time, detection of $17.0 \mathrm{~min}$, SCAN acquisition mode, $0.25 \mathrm{~s}$ acquisition time, SCAN mass/charge ratio $(\mathrm{m} / \mathrm{z})$ from 40 to 600 and $1 \mu \mathrm{L}$ injection volume.

\section{Phenolic compound quantification}

Total phenolic compounds were determined by the Folin-Ciocalteu spectrophotometric method (Cromoline) in triplicate (BERARDINE et al., 2005). The calibration curve was constructed using gallic acid (99\% purity). A stock solution of gallic acid $(500 \mathrm{mg} / \mathrm{L})$ was prepared and from this, subsequent dilutions were prepared $(0$, $50,100,150,250,500 \mathrm{mg} / \mathrm{L})$. Absorbance readings were performed at $765 \mathrm{~nm}$ using a UV-Visible spectrophotometer. The equation obtained from the gallic acid calibration curve 
was used and the results were expressed as $\%$ of gallic acid equivalent - GAE/100 mg.

\section{Minimal Inhibitory Concentration (MIC) and Disc Diffusion Determination}

For the evaluation of the concentration effect of the obtained extracts, the MIC technique was used, employing the Microdilution Broth Dilution Method (CLSI, 2015). The microdilution plates containing the antimicrobial agent were inoculated in each well using $100 \%, 75 \%, 50 \%, 25 \%$, $12.5 \%, 6 \%, 5 \%, 3.12 \%, 1.5 \%$ and $0.78 \%$ concentrations of the 6 extracts in BHI medium. Two microorganisms were analysed by plaques (E. coli CCCDE003 and $S$. aureus CCCDS007). In the wells of A-I, the extracts were placed in their dilutions along with the microorganisms, in well $\mathrm{J}$ the negative control (Chlorhexidine 2\%) was added and in well $\mathrm{K}$ the positive control was added with BHI broth and the microorganisms. After inoculation, the microdilution plates were incubated at $35^{\circ} \mathrm{C}$ for $24 \mathrm{~h}$ and the MIC was determined visually by solution turbidity (CLSI, 2015).

\section{Production of Minas Frescal cheeses}

Whole milk from a rural property in Uberaba, MG, was used to prepare the Minas Frescal cheeses used in the research work to investigate the antimicrobial effect of the extracts studied. The cheeses were prepared with three repetitions. Calcium chloride $(0.02 \% \mathrm{w} / \mathrm{v})$ dissolved in water, $6 \%$ of the extracts (separately), and the rennet (Ha-La, Chymosin enzyme, according to the manufacturer's recommendations), were added and the mixture was shaken for 3 min. The milk remained still during the coagulation process for $50 \mathrm{~min}$. Thereafter the curd was cut to yield grains $\mathrm{n}^{\mathrm{o}} 1(1.5 \times 1.5$ $\mathrm{cm})$. The curd stood for $3 \mathrm{~min}$. Subsequently, it was agitated for $5 \mathrm{~min}$., 1/3 of the whey was removed, $20 \% \mathrm{NaCl}$ was added, and the sample was placed into $500 \mathrm{~g}$ forms suitable for this type of cheese. After $30 \mathrm{~min}$., the first turn was performed, and after $1 \mathrm{~h}$ the second turn. The cheeses were packed in plastic bags and refrigerated at $8{ }^{\circ} \mathrm{C}$ (LOLLO et al., 2015).

Four formulations of Minas Frescal cheese were produced: Control Cheese without extract (CC), cheese with kernel extract of Coquinho mango (CKECM), cheese with peel extract of Espada mango (CPEEM), cheese with kernel extract of Espada mango (CKEEM), and cheese with kernel extract of Tommy Atkins mango (CKETAM). It is noteworthy that from the MIC study of the extracts it was observed that the concentration of $6 \%$ totally inhibited $E$. coli and $S$. aureus, and as a result, this was the extract concentration used in the products and the extracts used in the preparation of the formulations were chosen based on the results obtained in the analysis of phenolic compounds present in the extracts.

\section{Physical-chemical characterization}

The physical-chemical analyses were performed in triplicate on the fifth day after the cheeses were manufactured, up to which time they were stored under refrigeration at $8^{\circ} \mathbf{C}$. Analysis of acidity, $\mathrm{pH}$ (performed on days $0,5,10,15$ and 20 days of storage at $8{ }^{\circ} \mathbf{C}$ ), moisture, ash, fat and protein contents were performed, according to the Adolfo Lutz Institute protocols (ZENEBON et al., 2008; GOMES et al., 2011).

\section{Microbiological analyses}

The microbiological analyses followed the methodology of Guatemim et al. (2016). It was performed the determination of the most probable number of thermotolerant coliforms and the Listeria monocytogenes analysis. 


\section{Sensory analysis}

The sensory analysis of the produced cheeses was approved by the Research Ethics Committee of the UFTM (protocol 2.108.891). The panellists were instructed to read the Informed Consent Term (ICT) and after clarifying any doubts they might have about the subject of the study; they signed the ICT. This analysis counted on the participation of 72 untrained panellists aged between 18 and 63 years, made up of university employees and students. The formulations of Minas Frescal cheese used in the sensory analysis were prepared with pasteurized milk and were characterized microbiologically and physically-chemically before sensory analysis to offer safety samples in the sensory analysis.

The samples were cut in cubes $(3 \times$ $3 \mathrm{~cm}$ ) of approximately $25 \mathrm{~g}$ and served individually in plastic dishes, and duly identified with random 3-digit numerical codes. Samples were maintained at $8{ }^{\circ} \mathrm{C}$ and served simultaneously. The panellists were instructed to identify the codes of the samples in the sensory analysis sheet, from left to right, arranged in the tray, to record the score according to the hedonic scale score for each attribute: colour, aroma, texture, and taste and to finally rinse their mouth with water before trying the next sample. The test applied in this study was that of hedonic scale acceptance of nine points, where 1 corresponded to extremely disliked and 9 to extremely liked.

\section{Statistics}

The experimental design was made in randomized blocks. The data were analysed using the Analysis of Variance (F Test) at 5\% of probability and, once the significant effect of the treatment was verified, the Tukey test was applied, at 5\% probability. Statistical analyses were performed using Statistica 8.0 software.

\section{RESULTS AND DISCUSSION}

\section{Quantification of total phenolic compounds}

The amount of total phenolic compounds in the extracts studied ranged from $7.80 \mathrm{mg}$ GAE/100 $\mathrm{g}$ to $15.53 \mathrm{mg} \mathrm{GAE} / 100 \mathrm{~g}$ for the PEEM and KEEM, respectively (Figure 1). For all the samples there are significant differences in total phenolic compounds present in the peels. However, the quantity is relatively constant for all the samples in the case of the mango kernel. The amounts of total phenolic compounds founded are lower than those reported by Pinsirodom et al. (2018), who obtained 9.56 to $21.35 \mathrm{mg} \mathrm{GAE} / 100$ $\mathrm{g}$ for the peel extracts and 27.82 to 66.95 $\mathrm{mg}$ GAE/100 $\mathrm{g}$ for the kernel extracts of six mangoes cultivars. The authors also observed a higher content of phenolic compounds in the kernel extracts, which they indicated to be an important reservoir of such substances.

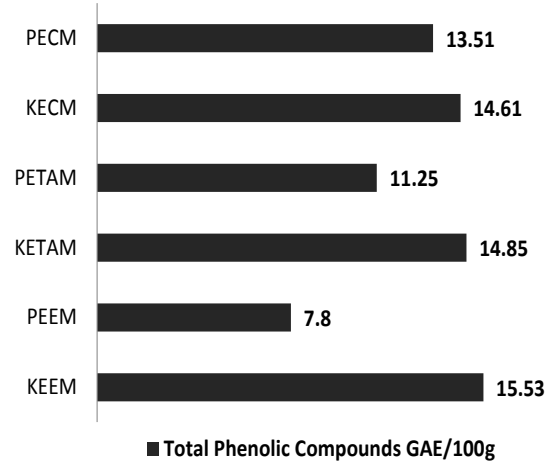

Figure 1 - Total phenolic compounds (GAE/100 mg) present in peel and kernel extracts of three mango varieties

Legend: Peel extract of Coquinho mango (PECM), kernel extract of Coquinho mango (KECM), peel extract of Tommy Atkins mango (PETAM), kernel extract of Tommy Atkins mango (KETAM), peel extract of Espada mango (PEEM), kernel extract of Espada mango (KEEM). 


\section{MIC and Disc Diffusion Determination}

The results obtained in the MIC and Disc Diffusion Method for all the extracts are listed in Table 1. Analysing the different extract concentrations, it is possible to verify that both tested microorganisms were sensitive to the extracts under study. The peel extracts were less effective than the kernel extracts, except for the Espada mango.

According to this result, although all the extracts were active, the kernel extract of Coquinho variety (KECM), the peel extract of Espada variety (PEEM), and the kernel extract

Table 1 - MIC and inhibition zones (between brackets, $\mathrm{mm}$ ) of the peels and kernels extracts of three Mango variety

\begin{tabular}{|c|c|c|c|c|c|c|}
\hline Concentration & PECM & КЕСМ & PEEM & KEEM & PETAM & КETAM \\
\hline \multicolumn{7}{|c|}{ E. coli } \\
\hline $100 \%$ & $0(25)$ & $0(23)$ & $0(25)$ & $0(22)$ & $0(18)$ & $0(21)$ \\
\hline $75 \%$ & $0(14)$ & $0(15)$ & $0(13)$ & $0(20)$ & $0(12)$ & $0(15)$ \\
\hline $50 \%$ & $0(13)$ & $0(12)$ & $0(10)$ & $0(18)$ & $0(12)$ & $0(15)$ \\
\hline $25 \%$ & $0(10)$ & $0(11)$ & $0(10)$ & $0(16)$ & $\begin{array}{c}\text { Bactericide } \\
\text { (11) }\end{array}$ & $0(13)$ \\
\hline $12.5 \%$ & $\begin{array}{c}\text { Bactericide } \\
(9)\end{array}$ & $0(11)$ & $0(8)$ & $\begin{array}{c}\text { Bactericide } \\
(10)\end{array}$ & - & $0(10)$ \\
\hline $6.25 \%$ & - & $\begin{array}{c}\text { Bactericide } \\
(10)\end{array}$ & $\begin{array}{c}\text { Bactericide } \\
(7)\end{array}$ & - & - & $\begin{array}{c}\text { Bactericide } \\
(9)\end{array}$ \\
\hline \multicolumn{7}{|c|}{ S. aureus } \\
\hline $100 \%$ & $0(16)$ & $0(23)$ & $0(23)$ & $0(20)$ & $0(14)$ & $0(23)$ \\
\hline $75 \%$ & $0(15)$ & $0(20)$ & $0(15)$ & $0(17)$ & $0(10)$ & $0(23)$ \\
\hline $50 \%$ & $0(14)$ & $0(20)$ & $0(13)$ & $0(15)$ & $0(8)$ & $0(20)$ \\
\hline $25 \%$ & $0(13)$ & $0(19)$ & $0(11)$ & $0(14)$ & $\begin{array}{c}\text { Bactericide } \\
\text { (8) }\end{array}$ & $0(19)$ \\
\hline $12.5 \%$ & $\begin{array}{c}\text { Bactericide } \\
\text { (10) }\end{array}$ & $0(15)$ & $0(10)$ & $\begin{array}{c}\text { Bactericide } \\
\text { (14) }\end{array}$ & - & $0(15)$ \\
\hline $6.25 \%$ & - & $\begin{array}{c}\text { Bactericide } \\
\text { (11) }\end{array}$ & $\begin{array}{c}\text { Bactericide } \\
\text { (7) }\end{array}$ & - & - & $\begin{array}{c}\text { Bactericide } \\
\text { (14) }\end{array}$ \\
\hline
\end{tabular}

Legend: Peel extract of Coquinho mango (PECM), kernel extract of Coquinho mango (KECM), peel extract of Tommy Atkins mango (PETAM), kernel extract of Tommy Atkins mango (KETAM), peel extract of Espada mango (PEEM), kernel extract of Espada mango (KEEM). 
of Tommy Atkins variety (KETAM) were the extracts with the highest antimicrobial activity.

\section{Physical-chemical analyses}

The results in percentages of each evaluated component are presented in Table 2. According to the Brazilian legislation (BRASIL, 2001), Minas Frescal cheeses are classified as having high moisture (values between 59.85 and $62.23 \%$ ), which was $60.03 \%$ for the control cheese in this study. The cheese with Espada mango kernel extract and the cheese with the Tommy Atkins mango kernel extract displayed no significant difference $(\mathrm{p}>0.05)$ compared to the control cheese. The cheese produced with Espada mango kernel extract $(60.27 \%)$ differed from the cheese produced with the peel extract of the same mango variety $(62.22 \%)$. The main effect of the high moisture in cheeses includes favouring microbial growth in the product. Khalifa et al. (2015) also verified higher moisture content in the cheeses with cranberry extracts.

The ash content in all treatments did not display statistical difference at the $5 \%$ level. Minas Frescal cheeses can present an average of 3.5 to $4.5 \%$ of ash according to the added salt content. Ashes or mineral residues are involved in curd formation, influencing the texture of the cheese, as calcium and phosphorus are the main structural elements in the curd.

Concerning lipid content, the obtained cheeses showed values of 16.10 to $18.43 \%$ of fat. For formulations with peel and kernel extracts no significant differences were observed at the 5\% level, showing that the addition of the extracts did not interfere with the characteristics of the product.

The protein contents were $\sim 18.68 \%$, presenting no significant difference at the 5\% level among the formulations. Similar results were found by Lollo et al. (2015) studying samples of Minas Frescal cheese and found $16.7 \%$ of protein.

The average of the results obtained for the $\mathrm{pH}$ of the cheeses at the different analysis times is presented in Figure 2(a). It is possible to observe that the mango peel (CPEEM) sample presented significantly higher $\mathrm{pH}$ over storage time, within the parameters established by the Brazilian legislation $(\mathrm{pH}$ 6.40 to 5.03$)$. It was observed that cheeses

Table 2 - Physical-chemical analysis of Minas Frescal cheese prepared with peel and kernels mangoes extracts

\begin{tabular}{ccccc}
\hline Treatments & Moisture \% & Ashes \% & Lipids \% & Proteins \% \\
\hline Control & $60.03^{\mathrm{b}}$ & $2.71^{\mathrm{ab}}$ & $18.43^{\mathrm{a}}$ & $18.83^{\mathrm{a}}$ \\
CKETAM & $62.23^{\mathrm{a}}$ & $2.64^{\mathrm{b}}$ & $16.80^{\mathrm{a}}$ & $18.33^{\mathrm{a}}$ \\
CKECM & $59.85^{\mathrm{b}}$ & $2.65^{\mathrm{b}}$ & $18.16^{\mathrm{a}}$ & $19.34^{\mathrm{a}}$ \\
CKEEM & $60.27^{\mathrm{ab}}$ & $2.74^{\mathrm{a}}$ & $17.66^{\mathrm{a}}$ & $19.33^{\mathrm{a}}$ \\
CPEEM & $62.22^{\mathrm{a}}$ & $2.68^{\mathrm{ab}}$ & $16.10^{\mathrm{a}}$ & $19.00^{\mathrm{a}}$ \\
\hline
\end{tabular}

Means followed by the same letters, in the same column, did not present significant differences according to Tukey's test, $\mathrm{p} \leq 0.05$. Legend: Control Cheese-without extract (CC), cheese with kernel extract of Coquinho mango (CKECM), cheese with peel extract of Espada mango (CPEEM), cheese with kernel extract of Espada mango (CKEEM) and cheese with kernel extract of Tommy Atkins mango (CKETAM). 
containing peel or kernel mango extract had a less pronounced decrease in $\mathrm{pH}$ values compared to the control cheese. This is due to the bacteriostatic effect of the extracts on microorganisms present in the cheese. Silva et al. (2003) found $\mathrm{pH}$ values of 6.2 to 5.0 in Minas Frescal cheese, values close to those found in this study. According to Khalifa et al. (2015), the inhibition of microbial growth observed for cranberry extract is directly linked to low $\mathrm{pH}$ and the presence of phenolic compounds in the extract. Thus, it can be assumed that as there are phenolic compounds in the extracts studied and the observed $\mathrm{pH}$ range is low, these factors may also be responsible for the antimicrobial activity observed in the extracts studied.

Figure 2(b) presents the results of acidity analyses, where the increase in the percentage of lactic acid during storage is verified. The increase in acidity was from $0.029 \%$ lactic acid to $0.056 \%$ lactic acid for the control cheese on day 0 and on the $20^{\text {th }}$ day, respectively. For the cheeses with added peel or kernel extract the results found were on average 0.024 to $0.043 \%$ lactic acid and there was no significant difference between the different types of extracts. The cheese without extract developed a significant increase of titratable acidity compared to other treatments. This shows that the extract seems to influence the natural microbial activity of the cheese, occurring characteristic fermentation during cheese storage.

The formation rate and amount of lactic acid produced influence the quality of the cheese, in addition to regulating the $\mathrm{pH}$ and the ionic balance, which is especially important in inhibiting the growth of potential pathogens. However, as previously mentioned, the presence of phenolic compounds in the extracts studied may also be related to antimicrobial activity and $\mathrm{pH}$. This is demonstrated in the present study, since the cheese with kernel extract of Espada (CKEEM) has the lowest $\mathrm{pH}$ on the $20^{\text {th }}$ day of study (after the control cheese) and the highest amount of phenolic compounds

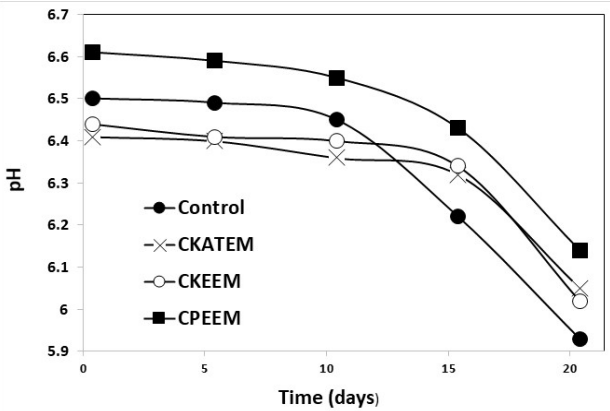

(a)

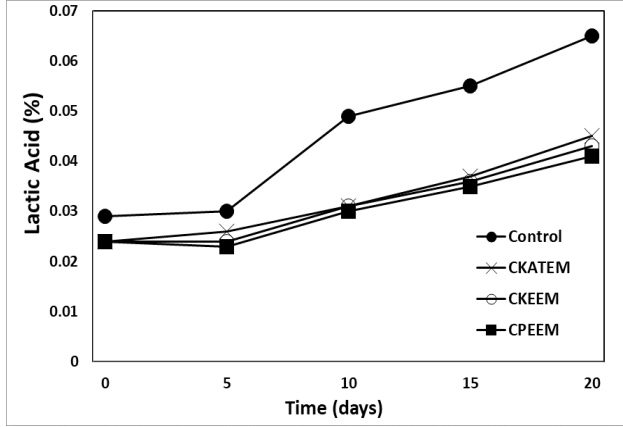

(b)

Figure 2 - (a) Results of the $\mathrm{pH}$ variation of the Minas Frescal cheeses from 0 to 20 days of storage. (b) Result of the acidity analysis of the Minas Frescal cheeses over the course of 20 days of added peel and kernel mango extracts

Legend: Cheese without extract (Control), cheese with peel extract of Espada mango (CPEEM), cheese with kernel extract of Espada mango (CKEEM) and cheese with kernel extract of Tommy Atkins mango (CKETAM). 
(15.5\%) of the extracts studied. The cheese with Tommy Atkins mango kernel extract (CKETAM), which has the second lowest $\mathrm{pH}$ (of the cheeses incorporating extracts) on the $20^{\text {th }}$ day of study, is the extract with the second highest number of phenolic compounds $(14.85 \%)$. Thus, it is verified that not only the amount of lactic acid produced, but the $\mathrm{pH}$ and the presence of phenolic compounds, which are linked to antioxidant activity, are also linked to the antimicrobial activity of cheeses containing bioactive extracts.

\section{Microbiological analyses}

The coliform counts at $45{ }^{\circ} \mathrm{C}$ over 20 days of storage are presented in Table 3. According to the Brazilian legislation, RDC $n^{\circ} 12 / 2001$ (BRASIL, 2001), Minas Frescal cheese must have a maximum limit of $5 \times 10^{2}$
$\mathrm{CFU} / \mathrm{g}$ of coliforms at $45^{\circ} \mathrm{C}$ for cheeses with lactic acid bacteria added, as in the case of cheese produced with raw milk for academic purposes. It can be observed in the Table 3 that the Control Cheese (without extracts) presented an increase in the microorganism count when compared to the cheeses with extracts. It is also observed that the cheeses formulated with the extracts had a less accelerated bacterial growth, arriving at day 20 with a count lower than that established by $\mathrm{RDC} \mathrm{n}^{\circ} 12 / 2001$. This is due to the bacteriostatic effect exerted by the extract on the coliform cells. The cheese with the extracts showed good resistance to microbial growth during storage.

The coagulase-positive Staphylococcus counts for the studied cheeses during the 20 days of storage are also presented in Table 3. According to RDC n $12 / 2001$, the Minas

Table 3 - Coliform at $45^{\circ} \mathrm{C}$ and coagulase-positive Staphylococcus populations in the cheeses during the 20 days of storage for the cheeses under study

\begin{tabular}{cccccc}
\hline \multicolumn{5}{c}{ Coliforms at $45{ }^{\circ} \mathbf{C}(\mathbf{M P N} / \mathbf{g})$} \\
\hline Treatments & Day 0 & Day 5 & Day 10 & Day 15 & Day 20 \\
\hline CC & $2.0 \times 10^{2 \mathrm{a}}$ & $4.2 \times 10^{2 \mathrm{a}}$ & $4.3 \times 10^{2 \mathrm{a}}$ & $1.0 \times 10^{3 \mathrm{a}}$ & $4.1 \times 10^{3 \mathrm{a}}$ \\
CKETAM & $9.4 \times 10^{\mathrm{b}}$ & $1.1 \times 10^{2 \mathrm{~b}}$ & $1.1 \times 10^{2 \mathrm{~b}}$ & $1.8 \times 10^{2 \mathrm{~b}}$ & $4.3 \times 10^{2 \mathrm{~b}}$ \\
CKEEM & $9.4 \times 10^{\mathrm{b}}$ & $1.1 \times 10^{2 \mathrm{~b}}$ & $1.1 \times 10^{2 \mathrm{~b}}$ & $1.8 \times 10^{2 \mathrm{~b}}$ & $4.3 \times 10^{2 \mathrm{~b}}$ \\
CPEEM & $9.4 \times 10^{\mathrm{b}}$ & $1.1 \times 10^{2 \mathrm{~b}}$ & $1.1 \times 10^{2 \mathrm{~b}}$ & $1.8 \times 10^{2 \mathrm{~b}}$ & $4.3 \times 10^{2 \mathrm{~b}}$ \\
\hline Coagulase-positive Staphylococcus $\mathbf{( C F U / g )}$ & \\
\hline Treatments & Day 0 & Day 5 & Day 10 & Day 15 & Day 20 \\
\hline CC & $5.82 \times 10^{2 \mathrm{a}}$ & $9.42 \times 10^{3 \mathrm{a}}$ & $5.6 \times 10^{4 \mathrm{a}}$ & $1.51 \times 10^{5 \mathrm{a}}$ & $3.06 \times 10^{5 \mathrm{a}}$ \\
CKETAM & $4.13 \times 10^{2 \mathrm{~b}}$ & $4.97 \times 10^{2 \mathrm{~b}}$ & $4.08 \times 10^{3 \mathrm{~b}}$ & $6.94 \times 10^{3 \mathrm{~b}}$ & $1.34 \times 10^{4 \mathrm{~b}}$ \\
CKEEM & $4.29 \times 10^{2 \mathrm{~b}}$ & $4.93 \times 10^{2 \mathrm{~b}}$ & $6.97 \times 10^{3 \mathrm{c}}$ & $8.47 \times 10^{3 \mathrm{~d}}$ & $2.89 \times 10^{4 \mathrm{~d}}$ \\
CPEEM & $4.38 \times 10^{2 \mathrm{bc}}$ & $6.78 \times 10^{2 \mathrm{~b}}$ & $5.33 \times 10^{3 \mathrm{~b}}$ & $7.19 \times 10^{3 \mathrm{c}}$ & $2.14 \times 10^{4 \mathrm{c}}$ \\
\hline
\end{tabular}

Means followed by the same letters, in the same column, did not present significant differences according to Tukey's test, $p \leq 0.05$. Legend: Control Cheese without extract (CC), cheese with peel extract of Espada mango (CPEEM), cheese with kernel extract of Espada mango (CKEEM) and cheese with kernel extract of Tommy Atkins mango (CKETAM). 
Frescal cheese should have a maximum limit of $5 \times 10^{2} \mathrm{CFU} / \mathrm{g}$ for cheese with lactic bacteria added, as in the case of cheese produced with raw milk for academic purposes. It is observed that the control cheese presented a large increase in the count when compared to cheeses with extracts. It can be observed that the counts for all the cheeses go beyond the limits established by RDC $n^{\circ} 12 / 2001$, at least in one of the studied days. The control cheese (CC) with $9.42 \times 10^{3} \mathrm{CFU} / \mathrm{g}$ is not suitable for consumption on the $5^{\text {th }}$ day, however, the cheeses with kernel extract of Tommy Atkins mango (CKETAM) and with kernel extract of Espada mango (CKEEM), exceed the limit only on the $10^{\text {th }}$ day with $4.08 \times 10^{3} \mathrm{CFU} / \mathrm{g}$ and $6.97 \times 10^{3} \mathrm{CFU} / \mathrm{g}$, respectively. Although the count exceeds the limit of the legislation, it is important to remember that the samples were prepared with raw milk to investigate the antimicrobial effect of the extracts. So, it can be noticed that the cheeses with extracts of kernels had a smaller microbial development when compared to the control cheese over 20 days.

For Salmonella and Listeria monocytogenes, RDC n ${ }^{\circ}$ 12/2001 establishes the absence of these microorganisms in the Minas Frescal cheese. For cheeses with peel and kernel extracts, for 20 days, the presence of neither Salmonella nor Listeria monocytogenes was not observed. For the control sample, the presence of both microorganisms was confirmed on day 15 and day 20, making consumption of this cheese unviable. According to Silva et al. (2003) and Kells et al. (2004), the presence of Listeria monocytogenes and Salmonella in dairy products has been increasingly common, especially in Minas Frescal cheese. In the dairy industry, the main routes of introduction of this pathogen are raw milk contaminated utensils and equipment, soil carried by worker's boots and clothing, air, ventilation system, water, and/or condensed water and transport cars, besides the possibility of being carried by workers or sick visitors (SWAMINATHAN, 2001). It is noteworthy that some strains of these microorganisms may remain in the processing environment for months or years. This makes it essential to use products like mango extract to inhibit the development of these bacteria.

\section{GC-MS Analysis}

The results obtained from the GC-MS analysis of the extracts are presented in Table 4. The composition of the peel and kernel extracts of the three different types of mangoes studied is different, and the difference for the kernel extracts is higher.

Some compounds are identified in all extracts, such as 1,2,3-benzenetriol and ethyl gallate, for the extracts of kernel and only ethyl gallate, for peel extracts. The sugar present in the kernel extracts of the Coquinho and Tommy Atkins (KECM and KETAM) mangoes is the same (fructose), but the sugar present in the extract of the Espada (KEEM) is sucrose. The kernel extract of Coquinho mango (KECM) presents the greater amount of carboxylic acids, followed by the kernel extract of Espada mango (KEEM). In the peel extracts, the Coquinho mango extract also presents the greater amount of carboxylic acids, followed by the Tommy Atkins extracts (PECM).

Considering the MIC of the extracts (Table 1), the peel extract of Espada mango (PEEM), kernel extract of Coquinho (KECM), and Tommy Atkins mangoes (KETAM) were the most active extracts, presenting MIC $6,25 \%$. Analysing the compounds present in the extracts (Table 4), it is possible to infer that in KECM the ethyl gallate and carboxylic acids are responsible for the biological activity, once in this extract is found the largest amount of carboxylic acid and the most variety of these compound, not found in the other extracts studied. 
In KETAM and PEEM is possible to say that maybe the ethyl gallate is responsible for the biological activity of these extracts. From Kalaivani et al. (2011), ethyl gallate is a food additive (E. number E313) and presents antiparasitic, anticancer, antimicrobial, radical scavenger multisystem antioxidant activities. The authors also showed the compound is cytotoxic, but only to tumour cells and cytotoxic mechanism is not related to membrane lytic properties or instability. Borges et al. (2013) showed the antimicrobial mechanism of phenolics products can involve various modes of action, i.e., destabilization and permeabilization of the cytoplasmatic membrane, enzyme inhibition by the oxidized products, and inhibition of nucleic acids synthesis. The disruption of the cell membrane by localized hyperacidification, which may alter cell membrane potential, making it more permeable, is a potential mechanism to explain the antimicrobial action of these compounds against microorganisms.

According to Ricke (2003), organic

Table 4 - Chemical components of the Mango extracts studied

\begin{tabular}{|c|c|c|c|c|c|c|}
\hline & \multicolumn{3}{|c|}{ KERNEL } & \multicolumn{3}{|c|}{ PEEL } \\
\hline & Coquinho & Espada & $\begin{array}{l}\text { Tommy } \\
\text { Atkins }\end{array}$ & Coquinho & Espada & $\begin{array}{l}\text { Tommy } \\
\text { Atkins }\end{array}$ \\
\hline Hexanoic acid & $\mathrm{X}$ & & & $\mathrm{X}$ & & \\
\hline Malic acid & $\mathrm{X}$ & & & & & \\
\hline 1,2,3-Benzenetriol & $\mathrm{X}$ & $\mathrm{X}$ & $\mathrm{X}$ & $\mathrm{X}$ & $\mathrm{X}$ & $\mathrm{X}$ \\
\hline 3-deoxi-D-Manoic lactone & $\mathrm{X}$ & & & $X$ & & \\
\hline D-glicero-D-galocto-heptose & $\mathrm{X}$ & & & & & \\
\hline Fructose & $\mathrm{X}$ & & $\mathrm{X}$ & & & \\
\hline Heptadecanol & $X$ & & & & & \\
\hline Ethyl gallate & $\mathrm{X}$ & $\mathrm{X}$ & $\mathrm{X}$ & $\mathrm{X}$ & $\mathrm{X}$ & $\mathrm{X}$ \\
\hline Pentadecanoic acid & $X$ & $\mathrm{X}$ & & & & \\
\hline Hexadecanoic acid & $\mathrm{X}$ & $\mathrm{X}$ & & & & \\
\hline Nonadecanoic acid & $\mathrm{X}$ & & & & & \\
\hline Sucrose & & $\mathrm{X}$ & & & & \\
\hline D-erythro-pentose & & $\mathrm{X}$ & & & & \\
\hline$\alpha$-D-galactopyranoside & & $\mathrm{X}$ & $\mathrm{X}$ & $\mathrm{X}$ & $\mathrm{X}$ & \\
\hline 17-Octadecynoic acid & & $\mathrm{X}$ & & & & \\
\hline $\begin{array}{l}\text { E-11-Hexadecenoic-ethyl- } \\
\text { ester }\end{array}$ & & $\mathrm{X}$ & & & & $\mathrm{X}$ \\
\hline Ethyl-tridecanoate & & $\mathrm{X}$ & & & & \\
\hline 2-deoxi-D-galactose & & $\mathrm{X}$ & & & & \\
\hline Decanoic acid & & $\mathrm{X}$ & & $\mathrm{X}$ & & \\
\hline Ethyl- $\alpha$-D-Glucopyranoside & & $\mathrm{X}$ & & & $\mathrm{X}$ & \\
\hline
\end{tabular}


carboxylic acids have been used as food additives and preservatives added to dairy, vegetable, and meat products for preventing food deterioration and extend the shelf life of food products. Moreover, the organic acids have been used as sprays incorporated as sanitizers during meat processing. This organic group includes the saturated straightchain monocarboxylic acids, their derivatives (unsaturated, hydroxylic, phenolic, and multicarboxylic). According to the author, generally, the cell wall, cytoplasmic membrane, and specific metabolic functions in the cytoplasm are the bacterial targets of antibacterial compounds, however, the antibacterial mechanism of organic acids is not completely understood. Despite that, organic acids can be bacteriostatic and bactericidal depending on the physiological status of the organism and the external environment. The undissociated forms of organic acids penetrate the lipid membrane of the bacterial cell and then dissociate into anions and protons. These species disturb the neutral $\mathrm{pH}$ in the cytoplasm and then the excess of protons tend to export, which causes adenosine triphosphate (ATP) consumption and cellular energy depletion.

There are some other antimicrobial mechanisms attribute to organic acids, which include the capabilities of organic acids to interfere with cytoplasmic membrane structure and membrane proteins (it may interfere in the electron transport and ATP production, which dissipate $\mathrm{pH}$ and electrical gradients across cell membranes), to interfere with nutrient transport, cytoplasmic membrane damage resulting in leakage, disruption of outer membrane permeability and influencing macromolecular synthesis (RICKE, 2003). However, Asif et al. (2016) explain that the antimicrobial action of kernel mango extract may occur by the leaking of bacterial cell membrane causing the membrane permeability to decrease. The authors explain there are two bacterial cell membrane terminations, the hydrophobic which is non-polar and reacts with the aliphatic side chain while the hydrophilic which is polar and embeds with the hydrophobic benzene ring and polar side of compounds present in the extract. Moreover, the antimicrobial action of kernel mango extracts on microbial metabolism occurs by inhibition of iron, oxidative phosphorylation, deficiency of the substrates necessary for microbial growth or inhibition of extracellular microbial enzymes.

Thus, it can be said that mango peel and kernel extracts, specially KECM, KETAM, and PEEM are suitable for use in food products as antimicrobial additives but can also be used for other antimicrobial purposes in the food industry. Pinsirodom et al. (2018) observed the presence of gallic acid, caffeic acid, p-coumaric acid, sinapic acid, and ferulic acid in six studied mango varieties, but they verified the changes of phenolic acid in the fruit extracts might be related to the fruit development and they also verified the total phenolics have been found to be higher in the kernel extracts than in the peel extracts.

\section{Sensory analysis}

The samples prepared for the sensory analysis were prepared with pasteurized milk, were characterized microbiologically before the sensory analysis and there was no microbial contamination. The sensory analysis of the cheeses produced in this study had 72 untrained panellists (54.86\% male and $45.20 \%$ female, aged 18 years to 54 years) and the results are presented in Table 5 .

It was observed that the control cheese (CC) presented the best average of notes in all the attributes. All samples presented a difference in coloration, and the sample of cheese with peel extract of Espada mango (CPEEM) received the lowest score. This may have occurred because the pigmentation of the peel altered the colour of the cheese more significantly and because the peel has a natural mango aroma and altered the cheese flavour. 
The most accepted sample according to the panellists, besides the control sample, was the cheese with kernel extract of Espada mango (CKEEM). According to the texture, the cheese with kernel extract of Tommy Atkins mango (CKETAM) presented the lowest score at 7.99 ("I liked moderately"), followed by the cheese with peel extract of Espada mango (CPEEM) which, statistically, did not differ between them. Considering the flavour, the cheese with kernel extract of Tommy Atkins mango (CKETAM) presented the best score after the control cheese (CC) followed by the cheese with kernel extract of Espada mango (CKEEM) and with the lowest score the cheese with peel extract of Espada mango (CPEEM). In general, all the samples were well accepted by the panellists, except for the formulation with peel extract of Espada mango.

\section{CONCLUSIONS}

The addition of the Espada mango peel extract contributed to the significant increase of moisture content compared to the control cheese. The cheeses with kernel and peel extracts had a lower evolution of titratable acidity and did not present total coliforms, Salmonella or L. monocytogenes over the 20 days of analysis. Therefore, it was verified that the lower the $\mathrm{pH}$ and the greater number of phenolic compounds in the extracts, the greater the antimicrobial action obtained in the cheese.

Despite small changes in the physicalchemical characteristics of the cheeses with added extracts, these presented good sensory acceptance. Thus, the results obtained in the present study suggest that the kernel extracts of Espada and Tommy Atkins mangoes can be used as functional ingredients, improving the shelf life of Minas Frescal cheese and that the addition of $6 \%$ of these extracts to the formulation of Minas Frescal cheese is recommended to obtain better antimicrobial activity and longer shelf life without affecting the sensorial characteristics of the final product.

\section{ACKNOWLEDGMENTS}

The authors thank FAPEMIG, CNPQ and CAPES. The sensory analysis was approved by the Research Ethics Committee of the UFTM (protocol 2.108.891).

\section{REFERENCES}

ABDALLA, A. E. M. et al. Egyptian mango by product 2: Antioxidant and antimicrobial activities of extract and oil from mango

Table 5 - Mean of the assigned scores of the hedonistic scale of 9 points, for the different formulations of Minas Frescal cheese and its attributes by the tasters in the sensorial analysis

\begin{tabular}{cccccc}
\hline Treatments & Colour & Aroma & Texture & Flavour & Acceptability \\
\hline CC & $8.95^{\mathrm{a}}$ & $8.42^{\mathrm{a}}$ & $8.73^{\mathrm{a}}$ & $8.93^{\mathrm{a}}$ & $9.00^{\mathrm{a}}$ \\
CKETAM & $8.81^{\mathrm{b}}$ & $8.06^{\mathrm{b}}$ & $7.99^{\mathrm{c}}$ & $8.43^{\mathrm{b}}$ & $8.32^{\mathrm{b}}$ \\
CKEEM & $8.84^{\mathrm{b}}$ & $8.23^{\mathrm{a}}$ & $8.21^{\mathrm{b}}$ & $8.01^{\mathrm{b}}$ & $8.32^{\mathrm{b}}$ \\
CPEEM & $8.68^{\mathrm{c}}$ & $7.95^{\mathrm{b}}$ & $8.05^{\mathrm{b}}$ & $7.08^{\mathrm{c}}$ & $7.94^{\mathrm{c}}$ \\
\hline
\end{tabular}

Means followed by the same letters, in the same column, did not present significant differences according to Tukey's test, $\mathrm{p} \leq 0.05$. Legend: Control Cheese without extract (CC), cheese with kernel extract of Tommy Atkins mango (CKETAM), cheese with kernel extract of Espada mango (CKEEM), and cheese with peel extract of Espada mango (CPEEM). 
seed kernel. Food Chemistry, v. 103, n. 4, p. 1141-1152, 2007. DOI: $10.1016 / \mathrm{j}$. foodchem. 2006.10.026

ASIF, A. et al. Therapeutic potentials of bioactive compounds from mango fruit wastes. Trends in Food Science \& Technology, v. 53, p. 102-112, 2016. DOI: 10.1016/j. tifs.2016.05.004

BARRETO, J. C. et al. Characterization and quantitation of polyphenolic compounds in bark, kernel, leaves, and peel of mango (Mangifera indica L.). Journal of Agricultural and Food Chemistry, v. 56, n. 14, p. 5599-5610, 2008. DOI:10.1021/jf800738r

BERARDINE, N. et al. Screening of mango (Mangifera indica L.) cultivars for their contents of flavonol $\mathrm{O}$ and xanthone C-glycosides, anthocyanins and pectin. Journal of Agricultural and Food Chemistry, v. 53, n. 5, p. 1563-1570, 2005. DOI: $10.1021 /$ jf0484069

BORGES, A. et al. Antibacterial activity and mode of action of ferulic and gallic acids against pathogenic bacteria. Microbial Drug Resistance, v. 19, n. 4, p. 256-265, 2013. DOI: $10.1089 / \mathrm{mdr} .2012 .0244$

BRASIL. Ministério da Saúde. Agência Nacional de Vigilância Sanitária. Resolução RDC n ${ }^{\circ} 12$, de 2 de janeiro de 2001. Aprova o Regulamento Técnico sobre Padrões Microbiológicos para Alimentos. Diário Oficial da União: seção 1, Brasília, DF, n. 7 , p. 45,10 jan. 2001 .

CLSI - Clinical and Laboratory Standards Institute. M07-A10: Methods for dilution antimicrobial susceptibility tests for bacteria that grow aerobically, approved standardtenth edition. Wayne: CLSI, 2015. 15 p.

DORTA, E.; LOBO, M. G.; GONZALEZ, M.
Reutilization of mango by-products: Study of the effect of extraction solvent and temperature on their antioxidant properties. Journal of Food Science, v. 71, n. 1, p. 80-89, 2012. DOI: 10.1111/j.1750-3841.2011.02477.x

GOMES, A. A. et al. Effect of the inoculation level of Lactobacillus acidophilus in probiotic cheese on the physicochemical features and sensory performance compared with commercial cheeses. Journal of Dairy Science, v. 94, n. 10, p. 4777-4786, 2011. DOI:10.3168/jds.2011-4175

GUATEMIM, E. L. X. et al. Evaluation of the microbiological quality of ricotta cheese commercialized in Santa Catarina, Brazil. Food Science and Technology, v. 36, n. 4 , p. $612-615,2016$. DOI: $10.1590 / 1678-$ $457 x .08716$

KALAIVANI, T. et al. Free radical scavenging, cytotoxic, and hemolytic activities of an active antioxidant compound ethyl gallate from leaves of Acacia Nilotica (L.) Wild. Ex. Delile subsp. Indica (Benth.) Brenan. Journal of Food Science, v. 76, n. 6, p. 144-149, 2011. DOI: 10.1111/j.1750-3841.2011.02243.x

KELLS, J. et al. Incidence of Listeria monocytogenes in two milk processing environments, and assessment of Listeria monocytogenes blood agar for isolation. International Journal of Food Microbiology, v. 91 , n. 2, p. $167-174,2004$. DOI: 10.1016/ S0168-1605(03)00378-7

KHALIFA, S. A. et al. Improving the quality characteristics of white soft cheese using cranberry (Vaccinium macrocarpon) fruit extract. International Food Research Journal, v. 22, n. 6, p. 2203-2211, 2015.

LOLLO, P. C. B. et al. Hypertension parameters are attenuated by the continuous consumption 
of probiotic Minas cheese. Food Research International, v. 76, n. 3, p. 611-617, 2015. DOI: $10.1016 /$ j.foodres.2015.07.015

PINSIRODOM, P. et al. Antioxidant activity and phenolic acid composition in different parts of selected cultivars of mangoes in Thailand. International Food Research Journal, v. 25, n. 4, p. 1435-1443, 2018.

RAVANI, A. et al. Mango and it's by product utilization - A review. Trends in PostHarvest Technology, v. 1, n. 1, p. 55-67, 2013.

RICKE, S. C. Perspectives on the use of organic acids and short chain fatty acids as antimicrobials. Poultry science, v. 82, n. 4, p. $632-639,2003$. DOI: $10.1093 / p s / 82.4 .632$

RUALES, J. et al. Biological active ecuadorian mango 'Tommy Atkins' ingredients - An opportunity to reduce agrowaste. Nutrients, v. 10, n. 9 , p. 1-14, 2018. DOI: 10.3390/ nu 10091138
SILVA, I. M. M. et al. Occurrence of Listeria spp. in critical control points and the environment of Minas Fresh cheese processing. International Journal of Food Microbiology, v. 81, n. 3, p. 241-248, 2003. DOI: $10.1016 / \mathrm{S} 0168-1605(02) 00223-4$

SWAMINATHAN, B. Listeria monocytogenes. In: DOYLE, M. P.; BEUCHAT, L. R.; MONTVILLE, T. J.(Eds). Food Microbiology: Fundamentals and Frontiers. Washington: ASM, 2001. p. 383-409.

TRIGO, J. P. et al. High value-added compounds from fruit and vegetable byproducts - Characterization, bioactivities, and application in the development of novel food products. Critical Reviews in Food Science and Nutrition, v. 60, n. 8, p. 1-29, 2019. DOI: $10.1080 / 10408398.2019 .1572588$

ZENEBON, O.; PASCUET, N. S.; TIGLEA, P. (coord.). Métodos físico-químicos para análise de alimentos. 4. ed., 1. ed. digital. São Paulo: Instituto Adolfo Lutz, 2008.1020 p. 